\title{
Municipal governance and environmental crises: threats and thoughts
}

\author{
EJ NEALER*
}

\begin{abstract}
Local government in South Africa (SA) has come a long way from the period when there were over 1200 racially segregated municipalities. From more than 800 municipalities after 1996, they have been merged to currently 284 municipalities which now cover every 'millimetre' of the country, and are focused on growing local economies and maintaining the provision of a lot more diverse and complex basic municipal services to all their citizens and especially to geographical areas and citizens that were previously neglected. This transformed local government environment has brought about many changes in the nature and extent of basic public services delivered at the grassroots level of this developing country with its limited resources and unlimited needs especially in the areas of potable water supply and sanitation services.

This article will firstly highlight the changed environmental context of public service delivery in the local government sphere of the country before the transformation in relevant legislation will be reported on. Subsequently the nature and extent of current realities of local governance, dynamics and challenges regarding the diverse and complex public services by a typical Category B Local municipality will be identified in the real SA out there. The use of the Politics - Administration System Model by Easton for environmental management analysis will also be illustrated. Lastly, for easy classification of typical characteristics and challenging issues in the dynamic municipal government sphere of SA, the SWOT-analysis format will be used.
\end{abstract}

Keywords: Local governance; Diversity and complexity; Environmental management; Potable water; Hydrological and geo-hydrological information; Water supply management; Water supply related legislation.

Disciplines: Public Management and Governance, Political Studies, Development Studies, Water Studies.

\section{Introduction}

The nature and extent of local government in South Africa (SA) have continuously been changing since 1996. Reddy (1999:10) defines this form and level of governance as '... local democratic units within the democratic system which are subordinate members of the government vested with prescribed, controlled governmental powers and sources of income to render specific local services and to control and regulate the geographic, social and economic development of defined local areas.'

There used to be more than 800 racially segregated local government sphere institutions consisting of inter alia, municipalities, town councils and village management boards scattered all over the country with some rural areas located at big distances away from existing infrastructure

* Prof Eric Nealer is subject head for Public Management \& Governance at the Potchefstroom campus of North-West University. E-mail: eric.nealer@nwu.ac.za 
and with no basic public service rendering. This negative state of affairs realised due to the fact that the previous government did not take responsibility for servicing the whole population of the developing country but only selected groups in certain geographical areas.

Due to the new democratic dispensation, urbanisation and globalisation the current ANC-led government has the responsibility to facilitate more effective, efficient, equal and economic basic service delivery to many millions more citizens over longer distances in a deteriorating physical environment. To achieve this objective the country has now been redemarcated with 230 Category B Local Municipalities covering it in a wall-to-wall manner. These Local municipalities are also grouped together in clusters of between 4 and 7 to form 47 Category C District Municipalities. The big cities like Johannesburg, Cape Town and Durban are taken up in 7 Category A Metropolitan Municipalities.

This article aims to identify some of the most important legislation and the transformation of it regarding the changed basic public service delivery on especially the local government sphere and by its public policy executing institutions. The Politics - Administration System Model and a SWOT (strengths, weaknesses, opportunities and threats) analysis will be used to identify and analyse some important environmental variables and primary actors at play in municipalities' quest to improved basic service delivery.

\section{Orientation and background}

Barrett and Jaichand stress the importance of potable water for the affairs of nation states and justify why its management and provision should be prioritized:

Water is life: we can live for only a few days without it. Water is death: contaminated, it can be as deadly as poison. Yet 1.1 billion of the 6 billion people on this planet have no access to an adequate water supply and 2.4 billion have no access to proper sanitation (2007:543).

With reference to SA as a semi-arid and developing country with a growing population and deteriorating physical environment, the following statement made by James Clarke as far back as 1991, should now be seriously considered:

Seventy one per cent of the Earth's surface is covered in water. While ninety eight per cent thereof is undrinkable sea water, only 1,2 per cent constitutes fresh water, which is locked in the polar caps and in glaciers. Consequently, inhabitants have a mere 0,8 per cent to inter alia, drink, irrigate their crops, manufacture steel, cool power stations, bath and transport sewage (Clarke, 1991:97).

In addition to the aforementioned one must be familiar with the so-called hydrological water cycle from rainfall to water runoff. It is a complex system where several processes (infiltration of water, surface water runoff, recharge of underground water aquifers, seepage, re-infiltration of water, and moisture recycling) are interconnected and interdependent with only one direction of flow: downstream (IUCN, 2005:22). The study of the nature, extent and behaviour of surface water runoff is called hydrology and that 
of groundwater is called geo-hydrology. The latter encompasses the effects and links between geology as the science and study of the earth, its history and the processes that shape it, and the place and role of water (hydrology). Here follows a graphical display of such a system:

\section{Figure 1: Hydrological Water Cycle (DWAF, 2008:On-line):}

It can be seen that the studies of hydrological and geo-hydrological aspects of importance in the quest for more effective, efficient, economical and

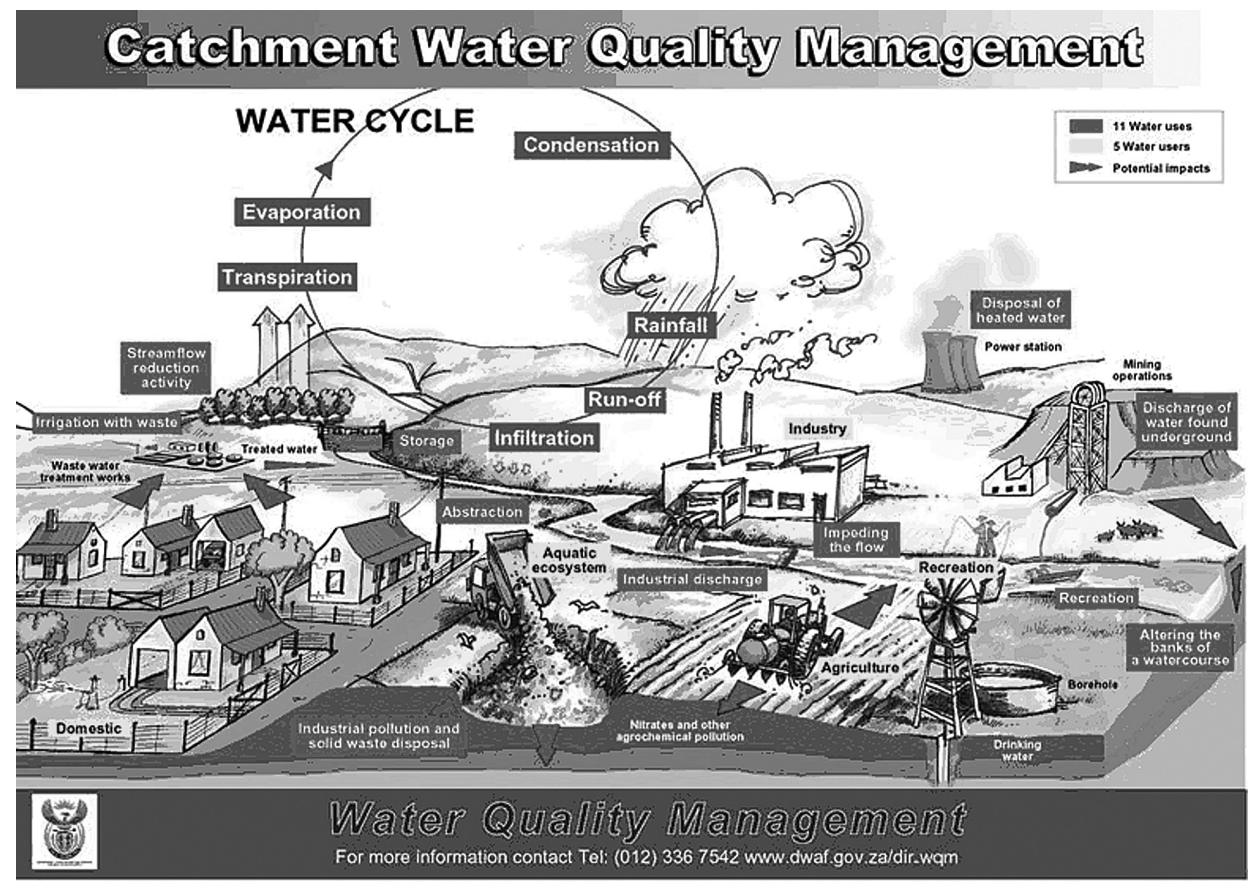

sustainable public management of water are typical of a rock science but not so difficult that they should be treated as a rocket science...

In the next section the transformed nature and extent of relevant legislation for the purpose of local government management and especially potable water supply management will be highlighted.

\section{Historical overview of legislative transformation}

The Constitution of the Republic of South Africa (Act 108 of 1996) arranges the so-called 'social contract' between the South African Government and the citizens of the country by the structuring of the three spheres of governmental legislature and execution of public policies. The Government is under a moral obligation to be sensitive to, identify, and in earnest take notice of the unlimited needs of the country's citizens and then by means of effective prioritization determine which of them should be addressed through effective and efficient public administration 
and management in an attempt to add value in the respective communities and the country's society as a whole.

In April 1994 the African National Congress won the first democratic election in South Africa and became the government-of-the-day. It immediately emphasised that its Reconstruction and Development Programme (RDP), as part of its political manifesto and foundation of all its new public policies, would be implemented and every effort be made to improve public service delivery in all three spheres of government. One of the four pillars of the RDP is 'meeting basic needs' of which access to basic water supply and sanitation services for all citizens of South Africa was made a priority (DWAF, 2004:4). Consequently, the former Minister of the Department of Water Affairs and Forestry (DWAF) (Prof Kader Asmal), during May 1994, initiated a process to review all waterrelated legislation (Gildenhuys, 1999:10). The overall objective of this process was to change the South African water dispensation so that socioeconomic demands and environmental management requirements would be met in as effective, efficient and economical manner as possible, and equal access for all South Africans would be provided (Pienaar \& Van der Schyff, 2005:263). As a result 17 new acts regarding the municipal environment and especially water management were promulgated between November 1994 and August 2005 to revisit existing executive public policies and produce new ones in furthering the developmental environment of the country as a whole.

\section{Nature and extent of local governance}

The local government sphere elections on 5 December 2000 ushered in a new system of local governance in South Africa. The newly structured and empowered local government sphere has been granted some degree of autonomy and expanded responsibilities (a shift to developmental local government) (Fast \& Engelbrecht, 1999:2). Prior to this date the municipalities were characterised by racial segregation, unequal allocation of resources and unequal delivery of basic public services. The legal and administrative structures inherited by the current Government did not serve the broad population of all the municipalities. Public participation - now a constitutional requirement - was non-existent (Motshekga, 2008:1). Consequently, all decision-making related to public service delivery was taken on behalf of the majority. In order to ensure that real integrated economic development and improved basic public services are delivered effectively and efficiently to the under-serviced communities, the municipal boundaries have been re-demarcated, newly merged municipalities with new organisational structures and policies have been formed and transformed organisational arrangements incorporated for more accessible and transparent citizen participation (Craythorne, 2006:51-54).

Governance, as distinct from government, is a relatively new concept that emerged as a policy idea during the 1990s. It flows from the recognition that power exists both inside and outside the formal structures of government and that the inter-relationships between government, private sector and civil society are critical factors affecting the performance of cities, regions and countries. It also stresses the 'process' as the place where decisions emerge from a complex set of relationships between many actors with different agendas. 'Urban 
governance is the sum of the many ways in which individuals and institutions (public and private) plan and manage the common affairs of a town/city. It is a continuing process through which conflicting or diverse interests may be accommodated and cooperative action can be taken' (UN HABITAT in South African Cities Network, 2006:4/51). In other words, it refers to how a city community organises itself, determines its priorities, allocates resources, selects who has a voice and holds each other to account. It is inextricably linked to the welfare of the citizenry with reference to inter alia, adequate shelter, security of tenure, safe water, sanitation, a clean environment, health, education, nutrition, employment and public safety and mobility.

With reference to national water affairs, the National Water Act 36 of 1998 was promulgated to provide for reform (improved equity, sustainability, efficiency and integrated water resources management) of the law relating to water resources in South Africa. Potable water is now recognised as a scarce and unevenly distributed national resource that belongs to all the people of the country and that the water collected in the various rainfall catchment areas (river basins and underground cavities, channels and fractures) and accumulated water resources (such as dams and underground water aquifers) should be managed in an integrated way (Fuggle \& Rabie, 2005:293). The key role-player in this environment is the Department of Water Affairs and Forestry (DWAF).

In the local government sphere of the developing South Africa, the effective, efficient and economical municipal management of potable water supply also entails the execution of highly complex hydrological, geo-hydrological and public management functions in a very dynamic and highly regulated environment. It inter alia entails the conserving of suitable water resources by firstly identification, surveying, and demarcation of such resources and then subsequently, the development, transport, treatment, distribution, imposition of tariffs, municipal administration, recollection of the used water, treatment and final release of the wastewater back into the water catchment for use by other downstream users. In addition, the nature and impact of the physical environment are also difficult to manage. It, therefore, requires the municipal managers, leading officials as well as the committed political office bearers to be equipped with specific knowledge and information regarding the physical environment and utilise geographical mapping tools in order to improve their long-term planning skills.

\section{Environment in which a municipality has to function}

In order to understand the place and role of a municipality in relation to the higher government spheres and the surrounding environment, the successful municipal manager and his/her subordinate municipal officials as well as the responsible political office bearers should adopt an integrated environmental management approach. This encompasses a sensitivity to, careful cognisance and holistic management of the aggregate of surrounding objects, conditions, and influences that impact on the life and habits of man or any other organism or collection of organisms' (Council for the Environment, 1989). The human environment 'would comprise the external circumstances, conditions, and factors that affect the existence and development of an individual or group'. In the context of development and conservation, this 'would consist 
of both a source of materials for creating circumstances that will improve the human condition, and a source of natural amenities and life-support systems which directly contribute to human well-being and survival' (Council for the Environment, 1989).

To assist in the aforementioned quest, the system theory is a handy tool which graphically illustrates that public policies are the result of demands that are set to the political system of the relevant country by the public. The political system is defined as the legitimate public institutions that have authoritative allotment of values and resources. These political institutions may be government departments in national, provincial or local spheres or parastatal institutions (Bayat \& Meyer, 1994:86 - 88). See Figure 2 for a simplified diagrammatical view of how, for example, the System Theory functions within the public sector in order to establish a more effective public service and general development.

\section{Figure 2: System Model towards improved development}

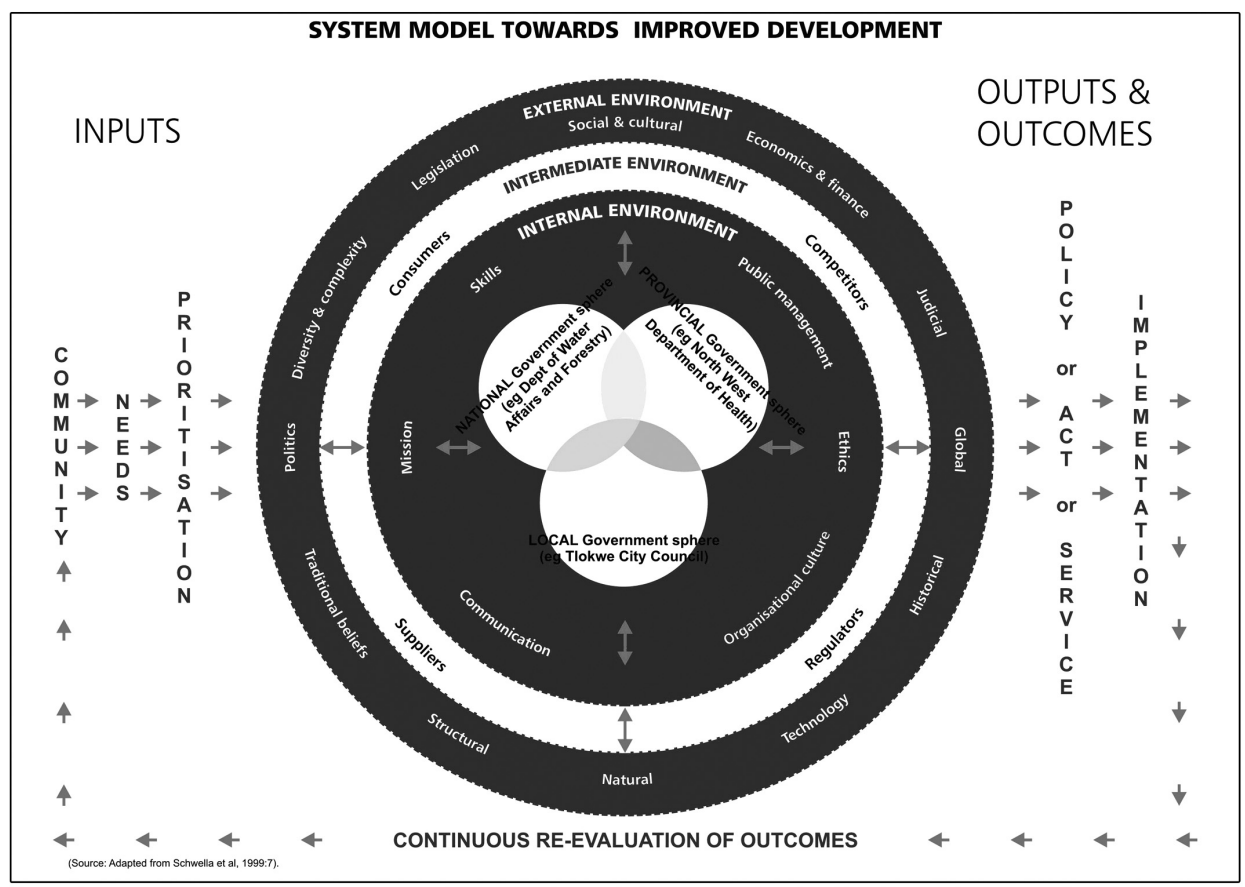

For easy classification of typical characteristics and challenging issues in the dynamic municipal government sphere of SA, the SWOT-analysis format will be used. The acronym SWOT stands for the strengths (S) and weaknesses (W) of an institution's intra- and internal position and the opportunities $(\mathrm{O})$ and threats $(\mathrm{T})$ that exist in the surrounding (external) environment. The SWOT-analysis is a technique that managers use to get an overview of the strategic position of an institution (Rossouw, 2007:70). 


\subsection{Strengths}

The following aspects can be identified as built-in advantages and resources which the municipal government sphere of a developing SA has at its disposal to further effective and integrated local development:

- The newly merged 284 municipalities which now cover every 'millimetre' of the country, are focused on growing local economies and maintaining the provision of a lot more diverse and complex basic municipal services to geographical areas and citizens that were previously neglected;

- from Table 1 presented in Section 3 one can distinguish that the change in government since April 1994 has produced an overall revisit to and transformation of existing executive public policies in furthering the developmental environment of the country as a whole;

- DWAF's National Water Act 36 of 1998 now makes provision for holistic and integrated water management according to surface water drainage regions;

- natural resources now are managed for the benefit of all the citizens of the country;

- more basic public services are now available to more citizens at more locations in the country in a more transparent and accessible manner;

- racial segregation, unequal allocation and delivery of basic services have been replaced with developmental local governance for all; and

- the mass media are playing an active and effective role in furthering basic service delivery and effective local governance.

\subsection{Weaknesses}

The following aspects can be identified as resources or competencies that municipalities have, but in short supply or of inferior quality compared with their competitors:

- SA is geographically a large semi-arid country with vast open spaces and scarcely habitable rural areas;

- prior to 2000, the South African municipalities were characterised by racial segregation, unequal allocation of resources and unequal delivery of basic services. Communities from previously disadvantaged areas had been subjected to discrimination and degrading living conditions. The legal and administrative structures inherited by the current Government did not serve the broad population of all the municipalities. Public participation - now a constitutional requirement - was non-existent;

- the financial management systems of many municipalities often do not allow for identification of costs and revenue streams from a particular service. This in turn means that it is not possible for municipalities to calculate, let alone charge tariffs that reflect the actual costs incurred for providing such a service (National Treasury, 2001);

- lack of attention to maintenance and sustainability of water 
management infrastructure with resulting high rates of water loss per capita due to internal leakages in houses and deterioration of the reticulation pipeline infrastructure;

- with the current urbanisation level of 56\% in the country (SACN, 2006:217), the newly established municipalities have much bigger geographical municipal areas and more residents to service and manage;

- a lack of effective municipal planning (Integrated Development Planning [IDPs] and budgets) which include aspects such as inter alia conducting municipal surveys and profiles of privately owned land and budgets in the restructuring, expansion and maintenance of local government infrastructure regarding basic services such as potable water and electricity supply, led to the current unmanageable status in most of the previously disadvantaged municipalities of the country; and

- the underlying causes of the ongoing failure of many municipalities to, for example, run a more preventive infrastructure maintenance programme and deliver a more reliable, effective, efficient and economical public service are due to inadequate budgets and skills (technical), inexperience in planning and implementing appropriate maintenance, and an absence of appropriate, credible and authoritative practice norms, standards and guidelines (CSIR, 2007:10).

\subsection{Opportunities}

The following aspects can be identified as major positive factors in the environment that put an institution in a better position to meet the needs of its customers than the positions of its competitors:

- In the global sphere the country is now part of the global village and through the means of modern communication technology it is within continuous reach of other countries and has to maintain optimal transparency of and access to aspects such as the nature and extent of its local governance. As foreign investors look for new sites, South African cities and local authorities will for example have to offer increasingly sophisticated telecommunications and freight infrastructure, desirable quality of life and a pool of highly skilled workers;

- all the leading political office bearers and public officials in leading positions should be submitted to continuous professional leadership, public management-, and environmental management training and also be equipped with more effective communication skills and the willingness to listen, look, learn and plan ahead. A clear ethical code of conduct must also be inculcated within their public service delivery to bring about and maintain effective, efficient and professional service rendering;

- in order to improve the organisational structuring and planning of the South African government, the provincial sphere of government should be merged into the national and local spheres and the functions and legislative authority of municipalities increased to bring about more effective and efficient 'greater city government' (Craythorne, 2006:42); 
- the coordination between key role-payers, the political office bearers, public officials, community organisations and residents should be improved. They should also try to liaise and communicate more freely with each other to learn more from each other and to strengthen their coordinated attempts to bring about more effective and efficient public service delivery (Daily Sun, 2006/03/20:On-line). This can only come true through more effective communication by means of for example newsletters, brochures, open days/launches and effective assistance from the mass media by focusing on important issues identified by the masses and promoting grassroots democracy and popular participation in development (City Press, 2005/11/27:On-line);

- with reference to internal aspects which a municipality should address, it is firstly recommended that a thorough strengths, weaknesses, opportunities and threats analysis (SWOT) as well as a skills and resources audit (survey) be carried out. This would assist a municipality to come up with more effective long-term planning aligned with an overall vision and mission, and its IDP;

- improved access to service delivery buildings and services as well as a more holistic approach to effective customer care should be arranged (such as chairs for older citizens and ample toilet facilities). For example, the cumbersome queuing techniques used in most public sector buildings must be investigated and improved (Daily Sun, 2005/ 05/12:On-line);

- environmental sensitivity towards and effective protection of the natural environment should be promoted through the numerous environmental laws which might be best achieved if all the available environmental conservation control and law enforcement mechanisms were fully utilised and all persons willing to participate in the enforcement process were allowed to do so (Loots in SAJELP, 1994:34);

- identify, survey, map and demarcate the nature and extent of a water drainage region with its rivers, marshes, fountains, groundwater, number of water users and consumers, quantity and quality of water and implement a well-defined, planned and orchestrated holistic management thereof;

- assist in the obtaining and supply of hydrological and logistical knowledge, skills and infrastructure to more correctly manage the identification, surveying, development, transport, storage, treatment, distribution, administering of tariffs, collection, storage and treatment of used and storm water and in the last instance return the treated used water (effluent) into the water catchment for use by downstream inhabitants;

- come up with more effective municipal infrastructure, policies, plans (such as IDPs and budgets) and training of municipal employees to improve public service delivery;

- active participation by a municipality on all public forums, legislatures, regulators and environmental watchdog associations;

- effective project management of 'planning by projects', communication plans and risk/disaster management plans should be incorporated;

- administrative and political willingness to put party-politics and 
overemphasised 'red tape' aside (albeit only for a few years) and to look, listen and learn in all earnest to bring about effective transformation and improvement in local governance and basic public service delivery towards economic growth, development and prosperity;

- conjunctive use of both surface (rivers) and underground (boreholes) water should be investigated and implemented by municipalities. Underground water which is less exposed to evaporation, is often of better quality (naturally pre-filtered) and provides a slow release of water to a cyclical surface water supply (DWAF, 2006);

- citizens should be informed about their rights and obligations with reference to the use and conservation of potable water. Continuous participation should also be encouraged by means of optimum access and transparency whenever local government issues are debated and decided upon;

- the committed, involved and experienced citizens should be encouraged to serve as informal contacts and advisors regarding more complex public service delivery activities such as the dangers of pollution to a town's/city's drinking water;

- the public service delivery infrastructure of a municipality should be maintained, developed, expanded, constructed and managed in a proactive, effective, efficient and economical way; and

- other more advanced geographical, geo-hydrological and information technological measures inter alia, GISs, river flow computer modelling, 1:10 000 scale ortho-photos, and satellite images should be researched and utilised to inculcate a butterfly view of a town's/city's primary natural environment determinants of the municipal management of, for example, its potable water supply.

\subsection{Threats}

The following aspects can be identified as major negative factors in the environment that put an institution in a weaker position to meet the needs of its customers than the positions of its competitors:

- There is too much centralization of Government's executive authority. Thus, national government departments constantly argue that they have to keep a tight control over how public funds are disbursed. This creates friction with municipalities;

- the nature and extent of governmental administration and management manifesting on the grassroots level entails more than the administration and service rendering by local municipalities itself. The ensuing local governance is made up from a complex set of intra, inter- and extra-governmental relationships between all three spheres of government, business and the community; an organisational and management shift away from a state-centred perspective to include civic associations, private-sector enterprises, community groups and social movements (SACN, 2006:3-52);

- urbanisation and more equal distribution of potable water and sanitation services to millions more inhabitants of the ever-expanding municipal areas brought about a serious increase in, for example, 
the handling of waste water and effluent in close vicinity to developed towns and cities. This has a subsequent increased potential threat of surface and groundwater pollution;

- the delivery of municipal services to a much bigger group of clients over longer distances is also characterised by a very high level of diversity (different types of functions) and complexity (different levels of skills and execution involved). Furthermore, the 'brain drain' of experienced and skilled municipal officials has resulted in increased work pressure for the municipal managers, officials and political office bearers;

- 'brown and black-outs' in electricity supply to especially the various potable and waste water pump stations as well as the implementation of a 'slow-down' in potable water supply should be managed in a more effective, efficient and economical manner;

- a tendency with community members of not being interested in the origin and management of their potable water as well as the destiny and management of their waste water and sewage. Just as long as the tap works and the toilet flushes effectively...;

- a 'flood' of new and unfamiliar water management terms used by service providers and regulators (e.g. Acid Mine Drainage, Dilution Capacity, Microcystins etc.) which are not clearly explained to the citizens in understandable language; and

- inaccurate and outdated population censuses which can affect effective planning in a negative sense.

\section{Conclusion}

The place and role of the local government sphere in SA are now clear, the necessary legislation and structures are in place, and the service providers must 'just get their act together' and start to implement and execute the governmental policies on the more effective and efficient rendering of public services to the citizens of the country. By taking 'baby steps' and tackling every unsatisfactory public service delivery challenge one by one in an integrated environmental management manner with effective public management procedures, a positive difference can be facilitated to ensure a better life for all!

\section{Bibliography}

BARRETT, D. \& JAICHAND, V. 2007. The right to water, privatized water and access to justice: tackling United Kingdom water companies' practices in developing countries. South African Journal of Human Rights, 23.

BAYAT, M.S. \& MEYER, H. 1994. Public administration: Concepts, theory and practice. Halfway House: Southern.

CLARKE, J. 1991. Back to Earth: South Africa's environmental challenges. Halfway House: Southern Book Publishers.

CITY PRESS. 2005. (On-line). Accessed on 2008.08 .15 at: http:// 152.111.1.251/argief/berigte/citypress/2005/11/27/C1/22/ 
02.html).

COUNCIL FOR THE ENVIRONMENT. 1989. Integrated environmental management in South Africa. Pretoria: Government Printer.

CSIR. 2007. The state of municipal infrastructure in South Africa and its operation and maintenance: An overview. Pretoria: CSIR.

CRAYTHORNE, D.L. 2006. Municipal administration: The handbook. Cape Town:Juta.

DAILY SUN. 2005. (On-line). Accessed on 2008.07.21 at: http:// 152.111.1.251/argief/berigte/dailysun/2005/05/12/DS/31/ 06.html).

DAILY SUN. 2006. (On-line). Accessed on 2008.07.29 at: http:// 152.111.1.251/argief/berigte/dailysun/2006/03/20/DS/31/ 01.html).

DEPARTMENT OF WATER AFFAIRS AND FORESTRY (DWAF). 2004. "A history of the first decade of Water Service delivery in South Africa 1994 to 2004". Pretoria: DWAF.

DEPARTMENT OF WATER AFFAIRS AND FORESTRY (DWAF). 2006. Guidelines for Water Supply Systems Operation and Management Plans During Normal and Drought Conditions. Pretoria: DWAF.

DEPARTMENT OF WATER AFFAIRS AND FORESTRY (DWAF). 2008. (Online). Hydrological water cycle. Accessed on 2008.07.07 at: http:/ /www.dwaf.gov.za/Dir_WQM/images / posters_CatchWQMBig.jpg.

FAST, H. \& ENGELBRECHT, B. 1999. Local Government Transformation: A guide for health workers" in Kwik-Skwiz 18, April 1999, p. 2.

FUGGLE, R.F. \& RABIE, M.A. 2005. Environmental management in South Africa. Cape Town: Juta \& Co,Ltd.

GILDENHUYS, A. 1999. "A new water dispensation". Butterworths Property Law Digest (Vol. 3, Part 1) p. 10.

IUCN. 2005. Water demand management. Pretoria: IUCN.

MOTSHEKGA, M. 2008. Lessons to be learned from the $19^{\text {th }}$ century on governance, which could enhance our current leadership in the development of local government sector (Paper delivered, Local Government SETA, Boksburg, March 2008), p. 1.

NATIONAL TREASURY. 2001. Intergovernmental Fiscal Review 2001. December 2001. Retrieved on 2007.03.13 from http:// www.finance.gov.za.

PIENAAR, G. J. \& VAN DER SCHYFF, E. 2005. (in JWN Tempelhoff [ed.]). African water histories: Trans-disciplinary discourses. Vanderbijlpark: North-West University.

REDDY, P.S. (ed.). 1999. Local Government Democratisation and Decentralisation: A Review of the Southern African Region. Cape Town: Juta.

ROSSOUW, D. 2007. Strategic management: An applied South African perspective. Claremont: New Africa Books (Pty) Ltd. 
SOUTH AFRICAN CITIES NETWORK. 2006. State of the cities report 2006. SACN.

SOUTH AFRICAN JOURNAL OF ENVIRONMENTAL LAW. 1994. Making Environmental Law effective. SAJELP, Vol 1 No 1. 